\title{
オーステナイト系不銹鋼のクリープ破断強度 と組織の変化についで
}

\author{
篠田軍治** 佐野忠雄** 桜井忠一*** \\ 川崎 正 ${ }^{* * *}$ 泉 久司***
}

Gunji Shinoda, Tadao Sano, Tadakazu Sakurai, Tadashi Kawasaki \& Hisashi Izumi: Studies on Creep Rupture Strength and Changes of Microstructure of Austenitic Stainless Steels. Creep rupture tests were carried out at $600^{\circ} \mathrm{C}$ on plain specimens and two different types of notched specimens, and the changes of their microstructure after creep test were examined. The specimens used were AISI type $304,304 \mathrm{~L}$ and an iron-base high-chromium high-nickel alloys. The creep rupture strength was not much affected by the notches of the specimen. The microstructures of specimens, which were ruptured after comparatively short time under comparatively higher stresses, revealed a large number of slip bands in each grain and a drastic deformation of individual grain. In the specimens ruptured after longer time, on the other hand, there appeared great many voids at the grain boundaries and a large amount of twin bands instead of slip bands or deformation of grains. These results may inform that the deformations or ruptures of specimens in both cases (short time rupture and longer time rupture) are caused by essentially different causes. Nevertheless, all the rupture datas, in each specimen, fall on a single straight line when they are plotted on logarithmic section paper.

(Received July 20, 1960)

\section{I. 緒 言}

オーステナイト系不銹鋼の高温引張強度ならびに高温疲 労強度について研究(1)(2)(3)を行つてきたが，これと関連し てクリープ破断強度について実験を行つた. 一般に機械部 品は断面変化など切欠をるつたものが大部分であるから， 切欠試料に対するクリープ破断強度を調べておくことは不

銹鋼を耐熱機械材料として使用する場合に必要なことであ る. そこで 3 種類のオーステナイト系不銹鋼について平滑 材ならびに切欠材のクリープ破断試験を行つた。

不銹鋼は長時間高温にさらされるとクロム炭化物, ある いは $\sigma$ 相の析出など組織上の变化が起るから(4), クリープ

\section{** 大阪大学工学部 $* * *$ 姫路工業大学}

* 1959 年 11 月: 本会大阪大会に発表

（1）篠田, 佐野, 桜井, 川崎, 泉: 本誌, 23 (1959), 645 .

（2）篠田, 佐野, 桜井, 川崎, 泉: 本誌, 24 (1960), 645.

(3) 篠田, 佐野, 桜井, 川崎, 泉: 本誌, 24(1960), 650.

(4) 今井, 藤村: 材料試験, 8(1959), 193,
中に括こる組織の変化やクリープ破断の型式などを調べる ために試験後, 破断した試験片について顕微鏡組織を観察 した.

\section{II. 試料ならびに実験方法}

実験に用いた試料は 18-8 系の 304 型, $304 \mathrm{~L}$ 型おょび $\mathrm{Cr}, \mathrm{Ni}$ とるに約 $20 \%$ 含むオーステナイト系不銹鋼で, 直 径 $19 \mathrm{~mm}$ 亿熱間圧延後 $1050^{\circ}$ で溶体化処理したものであ る. その化学成分の分析值は Table 1 の通りで, 組織は

Table 1 Chemical composition, in \%.

\begin{tabular}{l|c|c|c|c|c|c|c|c}
\hline \hline Mark & $\begin{array}{l}\text { AISI } \\
\text { type }\end{array}$ & $\mathrm{C}$ & $\mathrm{Cr}$ & $\mathrm{Ni}$ & $\mathrm{Mn}$ & $\mathrm{Si}$ & $\mathrm{Mo}$ & $\mathrm{Cu}$ \\
\hline $8 \mathrm{~S}$ & 304 & 0.07 & 18.48 & 8.47 & 1.00 & 0.50 & - & - \\
$8 \mathrm{~S} \mathrm{3}$ & $304 \mathrm{~L}$ & 0.03 & 18.75 & 11.37 & 1.40 & 0.54 & - & - \\
$22 \mathrm{~A}$ & - & 0.07 & 19.58 & 20.86 & 1.51 & 0.96 & 1.81 & 1.60 \\
\hline
\end{tabular}

いずれも一様なオーステナイト組織である.8 S 3(304 L型) は他の試料に比べて比較的結晶粒度が大きい。 
試料は溶体化処理後 Fig.1 に示す 3 種類の形状をもつ 試験片に旋削した。(a)の平滑試験片は直径 $9 \mathrm{~mm}$, 標点距

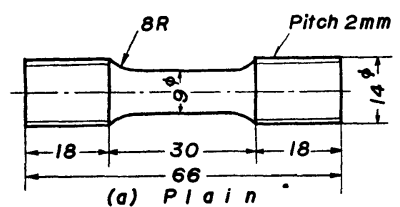

離 $20 \mathrm{~mm}$

である・

(b) (c)の

切欠の形

状係数 $\alpha_{k}$
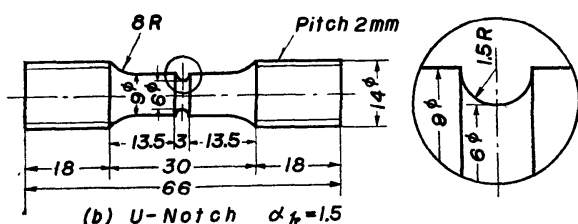

(b) $U$-Noteh $\alpha_{k}=1.5$

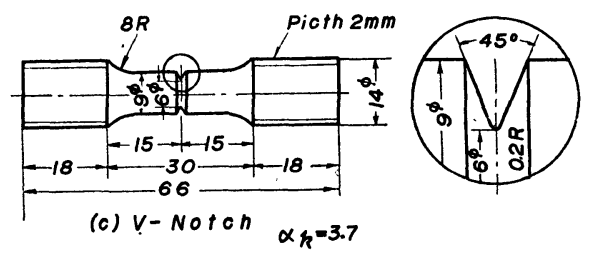

Fig. 1 Size of specimens.

で上昇させ $6 \mathrm{hr}$ 保持してから荷重を加えた。試験中試料 の温度は自動温度調節器によつて 調 整し, その変動は約 $\pm 3^{\circ}$ である. 顕微鏡組織の検鏡面はペーパー仕上げ 後 10 $\%$ 苳酸水溶液中で電解腐食した。

\section{III. 実 験 結 果ならびに考察} 1.クリープ破断強度

$600^{\circ}$ に扣けるクリープ破断試験の結果をFig.2に示した.

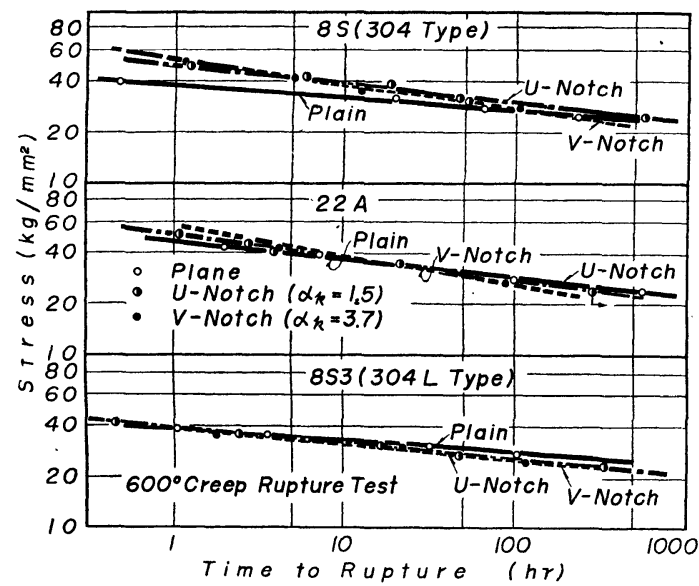

Fig. 2 Variation of time to rupture with rupture stress for austenitic stainless steels at $600^{\circ}$.
いずれの試料においても約 $500 \mathrm{hr}$ までの破断強度は切 欠 の形状や切欠の有無によつて殆んど差はないとみてよかろ 5.しかし 8S 試料では破断時間が短かい場合には切久試 料の方が僅かではあるが破断強度が高いようである.

不銹鋼のクリープ強度は炭素含有量にかなり敏感である (5). しかし炭素量の最も低い 8S 3 型の破断強度(Table 2, 3 参照) が他の鋼に比してあまり低くないのは結晶粒度が 他の鋼よりる大きいことに原因すると思われる。また $22 \mathrm{~A}$ が僅かに高い上5ではあるが, $\mathrm{Cr}, \mathrm{Ni}$ の高い22A が特に 強いという傾向はみとめられない，

このように $600^{\circ}$ における約 $500 \mathrm{hr}$ までのクリープ破断 試験では切欠の有無は破断強度に対してあまり大きな影響 を与えないことがわかつた。この点は短時間引張強度(1)や 疲労強度(2)と大いに趣を異にするところである。

Table 2 は $630^{\circ}$ に拈ける降伏点 $(0.2 \%$ 耐力), 抗張力,

Table $2630^{\circ}$ strength.

\begin{tabular}{l|c|c|c|c|c}
\hline \hline & $\begin{array}{c}\text { Carbon } \\
\text { content } \\
(\%)\end{array}$ & $\begin{array}{l}\text { Yield } \\
\text { point } \\
(\mathrm{kg} / \\
\mathrm{mm} 2\end{array}$ & $\begin{array}{l}\text { Tensile } \\
\text { strength } \\
(\mathrm{kg} / \\
\mathrm{mm} 2)\end{array}$ & $\begin{array}{l}\text { Enduran- } \\
\text { ce**limit } \\
\left(\mathrm{kg} / \mathrm{mm}^{2}\right)\end{array}$ & $\begin{array}{l}100 \mathrm{hr} * \\
\text { rupture } \\
\text { strength } \\
(\text { Plain) } \\
\left(\mathrm{kg} / \mathrm{mm}^{2}\right)\end{array}$ \\
\hline $8 \mathrm{~S}$ & 0.07 & 10.6 & 39.1 & 19.3 & 27.8 \\
$8 \mathrm{~S} 3$ & 0.03 & 8.4 & 28.9 & 14.0 & 27.6 \\
$22 \mathrm{~A}$ & 0.07 & 12.9 & 43.5 & 21.1 & 28.6 \\
\hline
\end{tabular}

* $600^{\circ}$ strength.

** The maximum repeated stress under which specimen will not fracture after $10^{6}$ times of repetition of stressing.

疲学強度および $600^{\circ}$ に扣ける $100 \mathrm{hr}$ クリープ破断強度を 示したもので, 降伏点や疲労限度はその温度に打ける抗張 力の高いものほど高い傾向がみられるにるかかわらず, $100 \mathrm{hr}$ 破断強度はいずれの試料もほぼ同じ值であり,その 值は約 $28 \mathrm{~kg} / \mathrm{mm} 2$ である。

また疲労強度は切欠のためにかなり低下するのが普通 で, 不銹鋼の高温疲労強度も切欠のため著しく低下した (2). 切欠試料扣よび平滑試料の $100 \mathrm{hr}$ なら゙に $500 \mathrm{hr}$ 破 断強度はTable 3 に示したよ 5 に,切欠によつてあまり低 下せず，かえつて增加する場合もある。

Fig.3 は標点距離 $20 \mathrm{~mm}$ の平滑試験片に打ける 破断伸 びと破断時間の関係で, 破断時間が長いものほど伸びは小 さくなつている．これは後に述べる顕微鏡写真の変化とと あに互いに関連がある. 破断強度は試料によつてあまり差 がなかつたが，破断伸びは試料によつてかなりの相違があ。 る.試料が破断したときの全伸びを破断までに要した時間 Table 3 Changes in $600^{\circ}$ creep rupture strength for the presence of notch.

\begin{tabular}{|c|c|c|c|c|c|c|c|c|c|c|}
\hline \multirow{2}{*}{ Mark } & $100 \mathrm{hr}$ & \multicolumn{2}{|c|}{$\begin{array}{l}\text { rupture strength } \\
\left(\mathrm{kg} / \mathrm{mm}^{2}\right)\end{array}$} & \multicolumn{2}{|c|}{ Notch factor } & \multicolumn{3}{|c|}{ 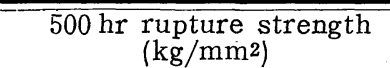 } & \multicolumn{2}{|c|}{ Notch factor } \\
\hline & $\begin{array}{c}\text { V-Notch } \\
\sigma_{V}\end{array}$ & $\begin{array}{l}\mathrm{U}-\mathrm{Notch} \\
\sigma_{u}\end{array}$ & $\begin{array}{c}\text { Plain } \\
\sigma\end{array}$ & $\sigma / \sigma_{r}$ & $\sigma / \sigma_{u}$ & $\begin{array}{c}\mathrm{V}-\mathrm{Notch} \\
\sigma_{V}\end{array}$ & $\begin{array}{c}\mathrm{U}-\mathrm{Notch} \\
\sigma_{u}\end{array}$ & $\begin{array}{l}\text { Plain } \\
\sigma\end{array}$ & $\sigma / \sigma_{V}$ & $\sigma / \sigma_{u}$ \\
\hline $\begin{array}{l}8 \mathrm{~S} \\
8 \mathrm{~S} 3 \\
22 \mathrm{~A}\end{array}$ & $\begin{array}{l}27.5 \\
24.8 \\
26.3\end{array}$ & $\begin{array}{l}30.0 \\
26.0 \\
27.5\end{array}$ & $\begin{array}{l}27.8 \\
27.6 \\
28.6\end{array}$ & $\begin{array}{l}1.01 \\
1.11 \\
1.09\end{array}$ & $\begin{array}{l}0.93 \\
1.06 \\
1.09\end{array}$ & $\begin{array}{l}22.2 \\
21.0 \\
22.0\end{array}$ & $\begin{array}{l}25.2 \\
22.0 \\
23.8\end{array}$ & $\begin{array}{l}24.5 \\
24.8 \\
25.0\end{array}$ & $\begin{array}{l}1.10 \\
1.18 \\
1.14\end{array}$ & $\begin{array}{l}0.97 \\
1.13 \\
1.05\end{array}$ \\
\hline
\end{tabular}

(5) E.J.Dulis, G.V.Smith and Hovsston: Trans. ASM, 45(1953), 42 , 
と応力と平均伸びはほぼ 直線関係となる。しかす 18-8 系 の 8 S と 8 S 3 は同一直線によつて表わされ，22A は 18-8

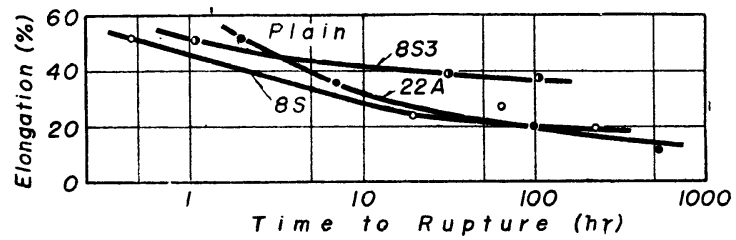

Fig. 3 Variation of elongation at rupture with time to rupture for austenitic stainless steels at $600^{\circ}$.

るが，試験片の先端や中央付近に拗いても全く闹様であつ た.またこの写真は一例として $8 \mathrm{~S}$ を挙げたが他の試料 でも同じ傾向であつた。このような事実は極く短時間で破 断する場合之，比較的長時間で破断する場合とではクリ一 プの变形機構が異なつていることを示するのであつて，応 力が大きく短時間で破断する場合には方りがおこつていた ことを示している. Photo.2 (b) で双晶がかなり彎曲して いるがこの原因は明らかでない、この詳紼については今後 の研究にまちたいと思う.

\section{3. 破断の型式}

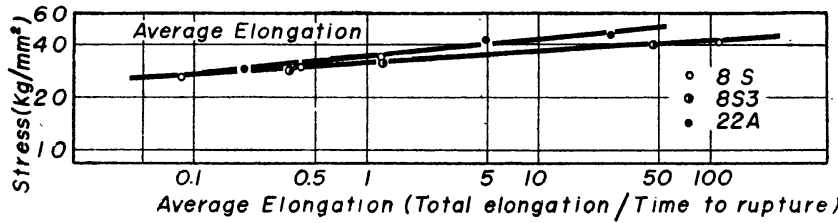

破断が約数十時間以内におこつたものは貫粒型 の破断であつて，しか子結晶粒は引張方向にか なり変形し，破断時間の短かからた陚料ほど著 しい変形を示している.Photo.3はその一部を 示したものである。写真の下段は応力が比較的小 さくて，破断時間が $100 \mathrm{hr}$ 以上のもので明らか に粒界型の破㯕であつて，結晶粒界に沿了て破断 stress for austenitic stainless steels at $600^{\circ}$. し，個々の結晶粒は殆んど変形していない。またこの場合， よりる傾斜がやや急で, 同一沁力に対する平均伸びは 18-8 系に比べて小さい.このことは Table 3 で示したように 平滑試料では 22A の抗クリープ性が 18-8 系よりやや高い 破断面近傍にある結晶粒の内部にはいずれる明瞭な双晶 が多数発生している. Photo. 3 は $8 \mathrm{~S}$ 陚料の写真で, 他の ことを示している．また平均絞りと 破断強度との関係も平均伸びと全く 同じ傾向を示した。

\section{2. 組樴 上の変化}

$8 \mathrm{~S}$ 試料を $630^{\circ}$ で $19.3 \mathrm{~kg} / \mathrm{mm}^{2}$ の応力を $1.0 \times 10^{6}$ 回 (約 $9 \mathrm{hr}$ ) 繰返 した場合には Photo.1 に示すよ 5 に，結晶粒内には極めて著しいこり 帯の発生がるられたが，同じ試料を $600^{\circ}$ で $25.1 \mathrm{~kg} / \mathrm{mm}^{2}$ でクリープ破 断試験後 $($ 約 $227 \mathrm{hr}$ ), 試料内の各部 を顕徽鏡で調べても之り帯は殆んど みられない.Photo.1は8S のみを 示したが他の試料についても同じ傾 向がみられた。このようにクリープ 破断試験では破断時間のいかんにか かわらず粒内にはこり帯が明瞭にみ られない．しかし応力が高くて破断 時間が極めて短かい場合，すなわち 破断時間が約数時間以内の場合に はクリープ 破断後試料を $600^{\circ}$ に約 $100 \mathrm{hr}$ 加熱すると， こり帯にクロム 岸化物などの著しい析出がみられる よ5になる.Photo.2 (a) はこれを 示したものである。一方応力が比較 的低く, $227 \mathrm{hr}$ で破断した試料は Photo.2 (b) に示したよ5に破断

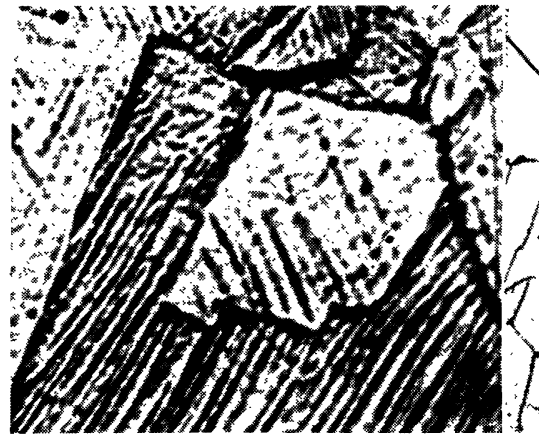

$8 \mathrm{~S} 630^{\circ}$ hot-fatigue $\left(630^{\circ}\right)$ $\times 800$ $\sigma=19.3 \mathrm{~kg} / \mathrm{mm}^{2}, \mathrm{~N}=1.0 \times 10^{6} \mathrm{cycle}$, $\tau \cong 9 \mathrm{hr}$

Photo.1 Microstructures show hot-fatigue test at $630^{\circ}$ and creep rupture test at $600^{\circ}$.

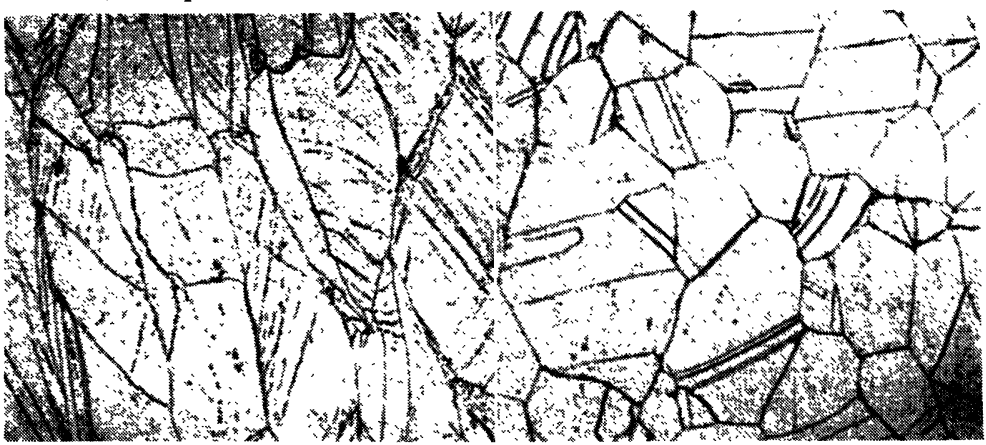
$\times 225$

(a) $\sigma=39.9 \mathrm{~kg} / \mathrm{mm}^{2}, \quad \tau=28 \mathrm{~min}$

(b) $\sigma=25.1 \mathrm{~kg} / \mathrm{mm}^{2}, \quad \tau=227 \mathrm{hr}$.

Photo.2 Microstructures of the $8 \mathrm{~S}$ specimen heated at $600^{\circ}$ for $100 \mathrm{hr}$ after creep rupture test at $600^{\circ}$, (a) and (b) are about $3 \mathrm{~mm}$ from rupture surface.
後, $600^{\circ}$ に加熱しても析出物は殆んどみられない。この写

真は破断面から約 $3 \mathrm{~mm}$ 内側のところを観察したものであ
陚料に捻いてもほぼ同じ傾向がみられた。これら他の試料 の写真を示すことは省略するが，破断時間が $1 \mathrm{hr}$ 前後の 
あのでは各結晶粒は著しく変形しているのみならず，いく らかの过り帯もみ兄ている．そして破断面付近には多数の

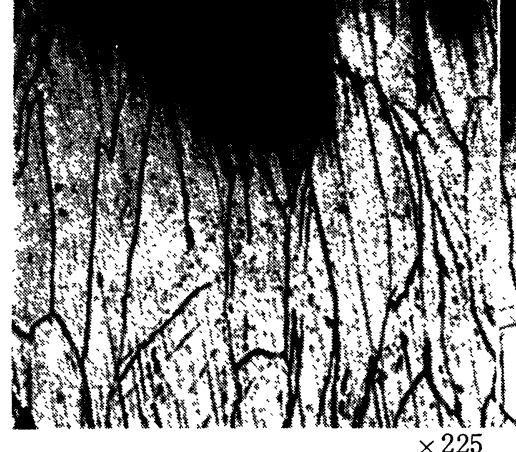

$8 \mathrm{~S}$ Plain-specimen $\sigma=39.9 \mathrm{~kg} / \mathrm{mm}^{2}, \tau=28 \mathrm{~min}$

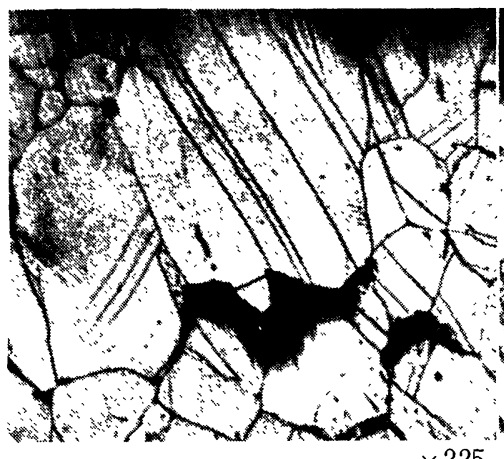

$8 \mathrm{~S}$ Plain-specimen $\sigma=25.1 \mathrm{~kg} / \mathrm{mm}^{2}, \quad \tau=227 \mathrm{hr}$ $\times 225$ Photo.3 Micro-structures showing transgranular type rupture (uper two) and intergranular type rupture(lower two) respectivery.

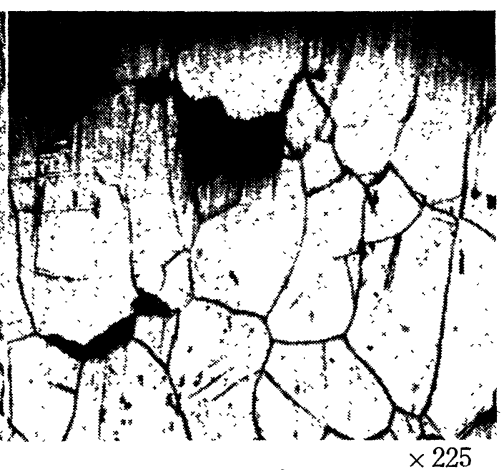

$8 \mathrm{~S}$ U-notch specimen $\sigma=38.0 \mathrm{~kg} / \mathrm{mm}^{2}, \quad \tau=18.3 \mathrm{hr}$

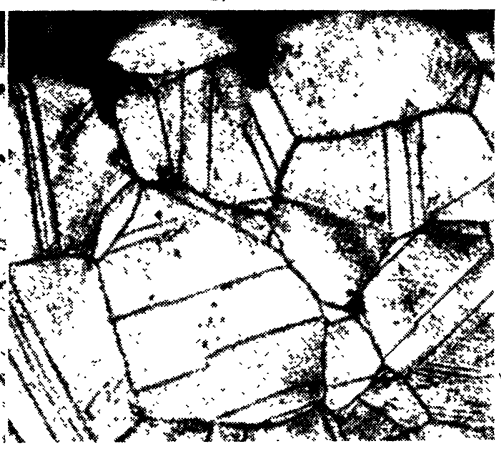

$\times 225$

$8 \mathrm{~S}$ U-notch specimen $\sigma=25.1 \mathrm{~kg} / \mathrm{mm}^{2}, \tau=553.5 \mathrm{hr}$
である.このように粒界に発生した空隙は時間の経過とと もに次第に大きく成長して他の空谅と連絡し，角裂となつ
て粒界破断を導くものと思われる。 Photo.4(b) (c) は空吵が大きなクラ ックにまで発澾した一例である。

以上の観察により $600^{\circ}$ に打ける クリープ破断の型式は破断時間によ つてつぎの゙っん分けることができ ๖.

（1）応力が 比較的大きく約 $1 \mathrm{hr}$ 内外の短時間で破断した場合で, 各 結晶粒は主として汇りによつて著し い変形をともない最後には結晶粒を 貫いて破断が持こる.

(2) 応力が小さくて数十壯間以上 の舆時間で破断する場合で，ほぼ完 全な粒界型破断であり，粒江知んど 変形していない. 破断面近傍の粒内 には多数の双晶が発生し, 破断面付 近には多くの空隚ができる。

そして両者の中間で破断する場合 には，(1) (2)の破断型式か茈合して いる。

（1）のように短時間で破断する場 合には多くのニり面でえりが物こ り, 普通の短時間引張試験の場合と ほぼ同じ過程を経て破断に至るもの

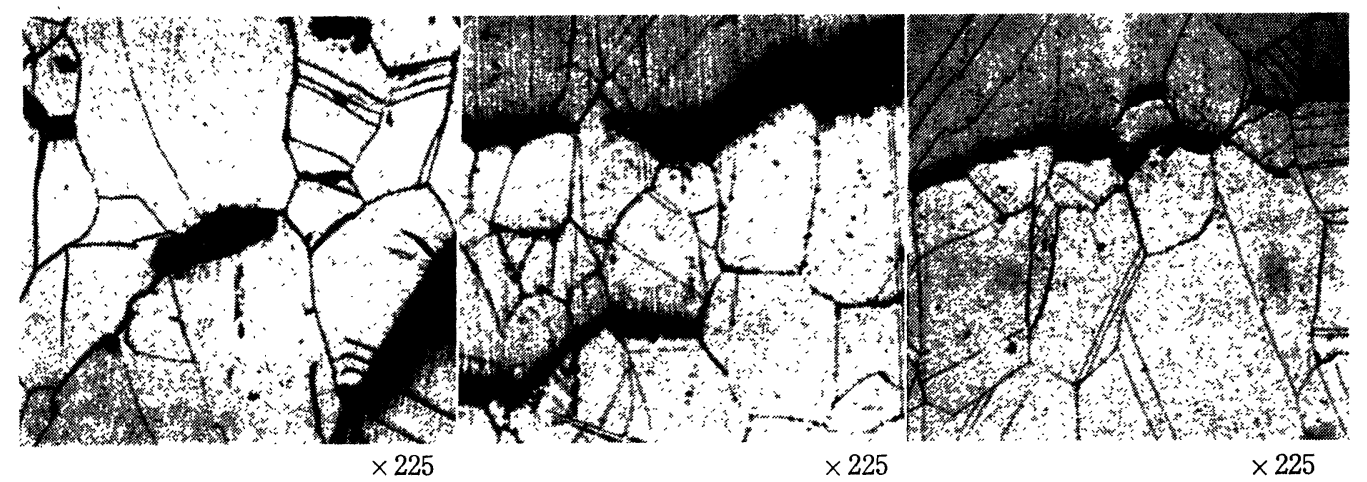

(a) $22 \mathrm{~A} \sigma=29.9 \mathrm{~kg} / \mathrm{mm}^{2}$,

(b) $8 \mathrm{~S} \sigma=25.1 \mathrm{~kg} / \mathrm{mm}^{2}$, $\tau=227 \mathrm{hr}$

(c) $8 \mathrm{~S} \quad \sigma=25.1 \mathrm{~kg} / \mathrm{mm}^{2}$, $\tau=227 \mathrm{hr}$

Photo.4 Microstructures of void in creep rupture test at $600^{\circ}$ of $22 \mathrm{~A}$ and $8 \mathrm{~S}$ plain specimens (a) is about $0.5 \mathrm{~mm}$ from rupture surface, (b) (c) are the same specimen and (b) is. about $1 \mathrm{~mm}$, (c) is about $2.5 \mathrm{~mm}$ from rupture surface.

空隙(void)がみられる.

Photo.4 は 8 S,22A 試料不々れる空隙の二三の例で, 平滑材では破断面から約 $5 \mathrm{~mm}$ 位の範囲に亘つて多数発生 して招り,Greenwood(6) が純銅や $\alpha$ - 黄銅でみとめたと同 様に応力が小さく, 破断時間の長いものほど著しく発生し て扔り,引張応力の方向に垂植な粒界に発生しているよう

(6) J.N.Greenwood,D.R.Miller and J.W.Suita: Acta Met., 2(1954),250.
である，一方 (2) の場合には荷重の瞬間には多少の亡りが おこつたとしても，その部分は加工硬化とか炭化物などの 析出によつて強化され，次ぎ次ぎに之りは抗こらない。す なわちこの場合の破断は（1)の場合と異なつた機構による あのであり, 詳細は今後の研究にまちたいが，ほぼ次のよ らに考えることができる.すなわち応力が働いているた めに原子空孔が高応力部一撰択的に拡散集合して(7)(8) 空 
隙を作り，空隌が互いに連絡して粒界破断に至るものであ ろち.

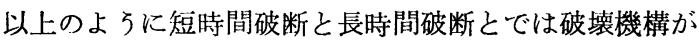
異なるよ5に思われる。しかし試験温度も600。だけであ りまた $500 \mathrm{hr}$ 以上の実験む行つていないので詳細は今 後の研究に譲りたい.

\section{IV. 結}

\section{흠}

オーステナイト系不銹鋼を $600^{\circ}$ で約 $500 \mathrm{hr}$ までのクリ 一プ破断試験を行つた. その結果

(7) F. R. N. Nabarro: Rep. Strength of Solid, (1948),75.

(8) A.H.Cottrell: Dislocation and Plastic Flow in Crystal, (1952), Oxford,22.
クリープ破断強度は高 $\mathrm{Cr}$, 高 $\mathrm{Ni}$ の不銹鋼がやや高い. また切欠の有無や形状がクリープ破断に扣よぼす影響は極 めて少なく, 平滑試料の $100 \mathrm{hr}$ クリープ破断強度は約 28 $\mathrm{kg} / \mathrm{mm}^{2}$ である.

大きな応力を加えて短時間で破断する場合と, 小さい応 力で $100 \mathrm{hr}$ 以上の長時間で破断する場合とでは試料のク リープ变形や破断の型式が異なつていることが明らかにさ れた.これは長時間クリープ強度を短時間試験の結果から 外そ弓的に判断することは組織学上不都命であることを示 するのである.

この研究に対し, 試料を提供された日本金属工業株式会 社ならびに終始実験に協力された日立製作所恒藤幸喜, 姫 路工業大学助手前川春已両君（いずれる当時姫路工業大学 生）に対し厚く感謝いたします。 